\title{
ОЦЕНКА ДОСТИЖЕНИЯ ЦЕЛЕВЫХ УРОВНЕЙ ТЕРАПИИ БОЛЬНЫХ САХАРНЫМ ДИАБЕТОМ 2 ТИПА
}

\author{
Тахирова Ф.А., Алимов А.В., Хайдарова Ф.А., Акрамова Г.Г.
}

Республиканский специализированный научно-практический медицинский центр эндокринологии имени академика Е.Х. Туракулова, Ташкент

ЦЕЛЬ: оценить состояние больных сахарным диабетом 2 типа по достижению целевых уровней углеводного обмена находящихся на различных схемах сахароснижающей терапии, кроме инсулинотерапии.

МАТЕРИАЛЫ И МЕТОДЫ: было оценено состояние 20 больных СД2, у которых проверили уровни гликемии натощак и через 2 часа после еды, определялся уровень гликированного гемоглобина по стандартизированному по DCCT методу, а также был определен уровень креатинина с высчитыванием скорости клубочковой фильтрации с помощью формулы CKD-EPI Creatinin 2009 Equation.

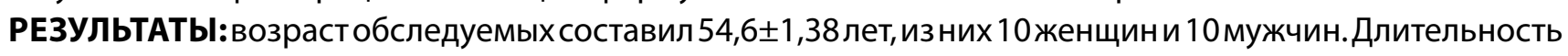

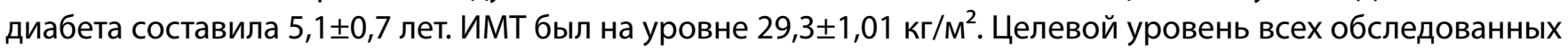

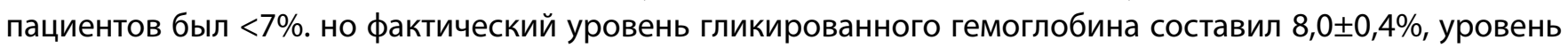

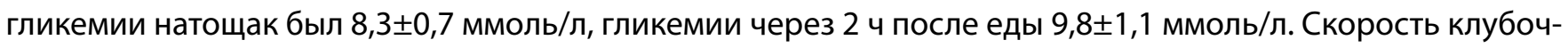
ковой фильтрации составила $84,1 \pm 4,1$ мл/мин.

ВывОды: наблюдаемые больные не достигали свой целевой уровень в<7\% и были в декомпенсированном состоянии. Отмечалось снижение СКФ, соответствующей второй стадии ХБП, в то время как длительность заболевания была сравнительно небольшой. Недостижение целевых уровней углеводного обмена в основном была связана в не соблюдении принципов здорового образа жизни, то есть нерациональном питании и гиподинамии, кроме этого отмечалась клиническая инертность лечащих врачей. 